last year by 4 . The causes of 55 , or 9 per cent., of the deathe registered in the eight towns during the week were not certified.

HEALTH OF DUBLIN.

The rate of mortality in Dublin, which had been $: 31.3$ and 30.0 per 1000 in the preceding two weeks, rose to 34.1 in the week ending April 16th. During the first quarter of this year the death-rate in the city averaged 30.9 per 1000 , the mean rate during the same period being but 17.8 in London and 19.4 in Edinburgh. The 231 deaths in Dublin last week showed an increae of 28 upon the number returned in the preceding week; they included 7 which were referred to measles, 6 to "fever" (typhus, enteric, or simple), 4 to scarlet fever, 4 to whoopingcough, 1 to diarrhoea, and not one either to small-pox or diphtheria. Thus 22 deaths resulted from these principal zymotic diseases, against 18 and 15 in the preceding two weeks; they were equal to an annual rate of 3.3 per 1000 the rates from the same diseases being $2 \cdot 2$ in London and 36 in Edinburgh. The fatal cases of measles exceeded the number returned in any previous week of this year, and the deaths from "fever," scarlet fever, and whooping-cough showed an increase upon those in the previous week. The deaths both of infants and of elderly persons also showed an increase upon the numbers in the previous week. Eight inquest cases and 9 deaths from violence were registered and 78 , or a third, of the deaths occurred in public institutions. The causes of 37 , or 16 per cent., of the deaths registered during the week were not certified.

\section{THE SERVICES.}

Deputy Surgeon-General W. Cattell has been appointed Principal Medical Officer at Cork.

Deputy Surgeon-General Sir J. A. Hanbury, K.C.B., embarked on the 21st inst. for Gibraltar, to take over the duties of Principal Medical Officer.

Surgeon General Simpson, Sanitary Commissioner with the Government of India and head of the Indian Medical Service in Bengal, comes home shortly in anticipation of his retirement from the service next autumn.

INDIA OFFICE.-The Queen has approved of the following admissions to the Indian Medical Service:-To be Surgeons (dated September 30th, 1886): Bengal-Robert Joseph Macnamara, M.D, Herbert Wilson Pilgrim, George Brooke French, Francis Wyville Thomson, Edwin Harold Brown, Charles Norman Bensley, Selby Herriot Henderson, David Wilson Scotland, Charles Robert Mortimer Green, James Henderson Sellick, Edward Christian Hare, Frank Cecil Clarksou, John Gregory Jordan, John Digby Marsh Swinburne, Herbert Mackinlay Morris, Allan Rupert Postance Russell, James Morwood, M.D., and Edmund Alexander William Hall. Madras-Gilbert Capel Hall, Richard Hendersen Castor, Frederick Geo. Maidment, Marie Joseph Toby Joinville Blancard, and Ignatius Purcell Doyle. Bombay-Blenman Buhot Grayfoot and Thomas Edward Dyson.

The following Officers, whose admission to the Indian Medical Service (Bengal) has already been notified, should have been placed in the following order:- William Grant Thorold, Patrick Hehir, Lionel John Pisani, Basanta Kumar Basu, Narendra Prasanna Sinha, Wm. Rice Edwards, Charles Mactaggart, John Fenton Evans, George James Framilton Bell, Joseph Thomas Daly, Menry Fooks, Ernest Hudson, Arthur Cecil Deare, Arthur William Dawson, William Henry Banner Robinson, and Henry Anderson Sheppard.

Adminaltr. - Staff Surgeon Robert George Bird has been promoted to the rank of Fleet Surgeon in Her Majesty's Fleet (dated April 11th, 1887).

The following appointments have been made:- Surgeon Thomas Nunan, to the Wasp (to date from 21st inst.); Mr. James P. Smith, to be Surgeon and Agent at Ullapool; and Mr. T. E. Mellerick to be Surgeon and Agent at Waterville.

RIFLE VoLUNTEERS- -5th Durham: Surgeon and Ilonorary Surgeon-Major P. Brown resigns his commission; also is permitted to retain his rank, and to continu $\theta$ to wear the uniform of the corps on his retirement (dated April 16th, 1887).-2nd Shropshire : George Hollies, Gent., to be Acting Surgeon (dated April 16th, 1887).
(T)arespondente.

$$
\text { "Audi alteram partem." }
$$

\section{PUNCTURE BY TROCAR OF THE TYMPANITIC} ABDOMEN IN PUERPERAL CASES.

To the Editors of THE LANCET.

Sras, - May I be allowed to correct an error into whicls Dr.W. O. Priestley has inadvertently fallen, through my fault, in his note on the above subject in your issue of April 9th, After remarking that Major Franklin had said that he recollected some suggestion of mine concerning tapping in such cases, he adds, "and Dr. Hicks tells me that though he had suggested it as applicable under certain circumstances, he had not himself employed it." At the time Dr. Priestley spoke to me on this subject I did not remember that the last of four published cases which I had nyself done was after a case of Cresarean section. This case occurred in 1867. The report was read before the Obstetrical Society of London in 1868, and published in vol. x., 1869. In one of your contemporaries of that year the matter was discussed by others as well as myself, cases being narrated, and questions of priority raised showing that a number of quite independent practitioners had been relieving tympany by trocar; but it appeared that it had been employed in France earlier than here. It was afterwards discussed in the Clinical Society and published in its Transactions, I believe that with care this operation might be had recourse to more frequently than hitherto in cases of severe distension, where the depression caused by the generally accompanying peritonitis is much intensified by the pressure on the sympathetic system. In any case, I can answer for an enormous relief to the sufferings of the patient, and in some cessation of the constipation resulting from the over-distension of the bowels by the gaseous contents.

I am, Sirs, yours truly, J. BRAXTON Hicks,

George-street, Hanover-square, April 18th, $188 i$.

\section{To the Editors of THE LANCET.}

Sirs,--In 1875, while house-physician at St. Bartholomew's. a case of scirrhus of the rectum was under my care. The patient suffered acutely from distension due to flatus. I therefore asked the house-surgeon to puncture the colon. His refusal may be taken as indicating that this little operation was not fashionable in those days. Hence this short illustrative note. I at once inserted a fine exploring trocar. While the gas was issuing from the cannula, the patient loudly proclaimed the relief attending its exit. One may fairly presume that the puerperal cases are not unfavourable to the performance of this simple but effectual operation; but surely the necessity for its employment seldom occurs. I am, Sirs, yours faithfully,

April 20th, 1887. T. H. SAWTWLL, M.D. Lond.

\section{THE MARGARET-STREET INFIRMARY} APPOINTMENTS.

\section{To the Editor's of THE LANCET.}

Srrs,-Will you allow me, as one of those who have accepted vacant posts in the above institution, to submit, with all respect, that in your implied censure (in the annotation this week) of any who are not "avowed homoepathists" for accepting such vacancies you seem to take up an untenable position? The presence of homoeopathists on the staff is either prejudicial to the interests of the patients or it is not. If the former, then the action of medical men -not avowed homoeopathists--in joining the staff deserves your approbation, since by diluting homceopathic influence and diminishing homoeopathic practice, they would tend, ex hypothesi, to augment the advantages and lessen the risks of the patients. If, on the other hand, homoeopathists do not imperil the welfare of the patients, there is no justification for your condemnation of those who choose to serve in the same charity as they. You may hold that I bave not stated the real point at issue, and maintain that it is prom fessional honour which is at stake, in which case it appears to me you would exalt the importance of boycotting certain 